\title{
Ammonia Measurement
}

National Cancer Institute

\section{Source}

National Cancer Institute. Ammonia Measurement. NCI Thesaurus. Code C74799.

The determination of the amount of ammonia present in a sample. 